\title{
Chaucer's General Prologue to the Canterbury Tales
}

An Annotated Bibliography 1900 - 1982

The General Prologue to Chaucer's Canterbury Tales is one of the most enduring works of English literature. Beloved by scholars, teachers, students, and general readers, it has been given a great many different interpretations. This annotated, international bibliography of twentieth-century criticism on the Prologue is an essential reference guide. It includes books, journal articles, and dissertations, and a descriptive list of twentieth-century editions; it is the most complete inventory of modern criticism on the Prologue. The extensive annotations provide uniquely convenient access to many publications that are otherwise difficult to obtain.

In her introduction, Caroline Eckhardt provides a careful and comprehensive overview of modern trends in criticism, trends which can be traced through the bibliography. At the beginning of the century, for example, Chaucer's Prologue was often described as a 'portrait gallery' and praised for its realism - social, psychological, and dramatic. Later in the century came emphases on irony, rhetoric, Freudian interpretations, elaborate allegories, and stylistic complexities. At present, the Prologue is often interpreted as a system of signs and symbols in which realism, if it exists at all, serves purposes beyond itself. The smiling and serene poet of the earlier period has been replaced by a self-conscious ironist, sometimes with a split personality. The portrait gallery of the beginning of the century is still there, though the spectator who walks along it tends to see something less fixed textually (the Prologue is now commonly discussed as work-in-progress) and more complicated structurally, generically, and thematically. It is the spectator, of course, who has changed.

CAROLINE D. ECKHARD'T is a professor of English and Comparative Literature at Pennsylvania State University. 
The Chaucer Bibliographies

\section{GENER AL EDITOR}

Thomas Hahn University of Rochester

\section{ADVISORY BOARD}

Derek Brewer Emmanuel College, Cambridge

Emerson Brown, jr Vanderbilt University

John Hurt Fisher University of Tennessee

David C. Fowler University of Washington

John Leyerle University of Toronto

James J. Murphy University of California, Davis

Russell A. Peck University of Rochester

Florence H. Ridley University of California, Los Angeles

Paul Ruggiers University of Oklahoma

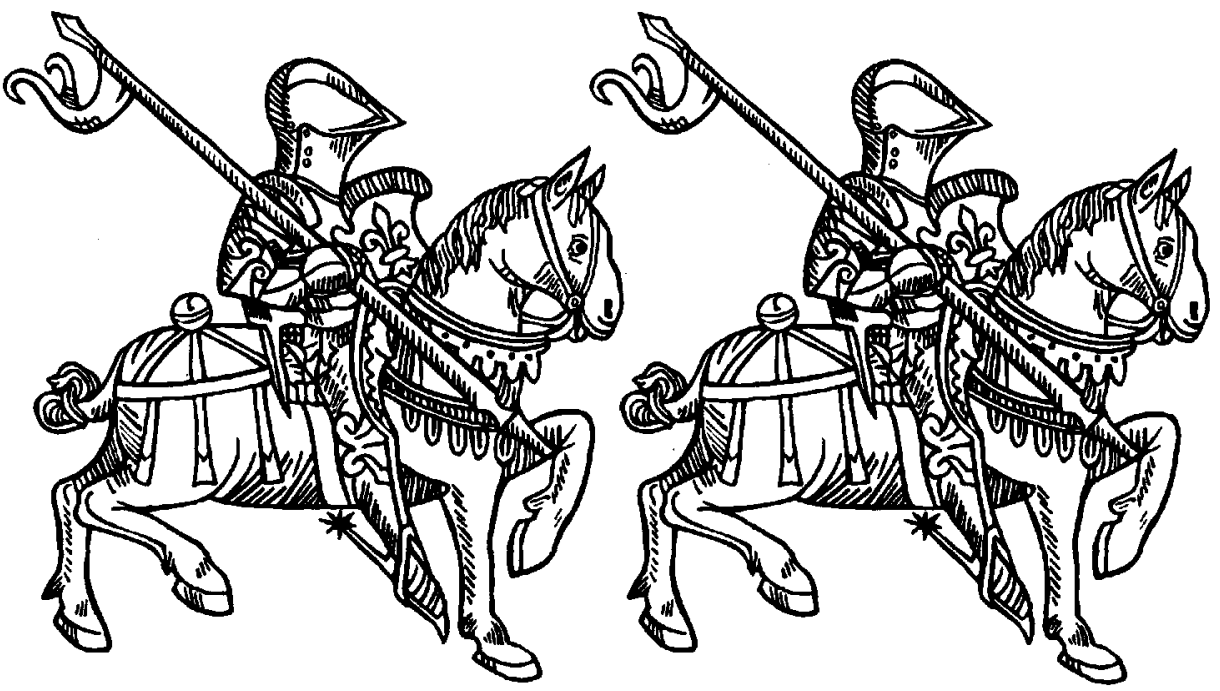




\section{Chaucer's \\ General Prologue to \\ the Canterbury Tales}

AN ANNOTATED BIBLIOGRAPHY

1900 to 1982

Caroline D. Eckhardt

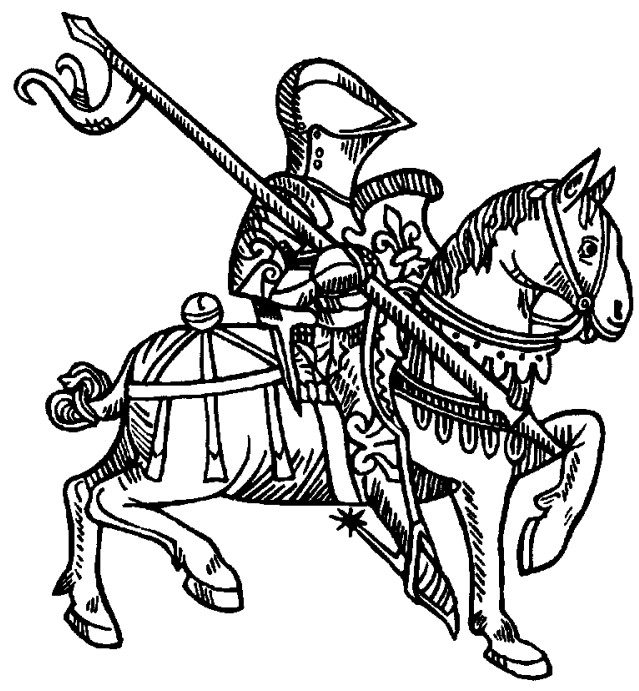

Published in association with the University of Rochester by

UNIVERSITY OF TORONTO PRESS

Toronto Buffalo London 


\section{www.utppublishing.com}

OUniversity of Toronto Press 1990

Toronto Buffalo London

Printed in Canada

ISBN 0-8020-2592-7

(6)

Printed on acid-free paper

\section{Canadian Cataloguing in Publication Data}

Eckhardt, Caroline D., 1942-

Chaucer's General prologue to the Canterbury tales

(The Chaucer bibliographies; 3 )

ISBN 0-8020-2592-7

Includes index.

1. Chaucer, Geoffrey, d. 1400. Canterbury tales.

Prologue-Bibliography. I. Title. II. Series.

Z8164.E34 $1990 \quad$ 016.821'1 $\quad$ C89-090531-2 
For R.B.E. 
This page intentionally left blank 